\title{
SURVEI KESEHATAN TENGGOROKAN DI DESA TINOOR DUA
}

\author{
${ }^{1}$ River J. Wiyanto ${ }^{1}$ \\ ${ }^{2}$ Olivia C. P. Pelealu \\ ${ }^{2}$ R. E. C. Tumbel \\ ${ }^{1}$ Kandidat Skripsi Fakultas Kedokteran Universitas Sam Ratulangi Manado \\ ${ }^{2}$ Bagian/SMF Telinga Hidung Tenggorok-Bedah Kepala Leher Fakultas Kedokteran \\ Universitas Sam Ratulangi Manado \\ Email: riverwiyanto@gmail.com
}

\begin{abstract}
Pharyngitis is a common disease in adults and children. Approximately $15-30 \%$ of pharyngitis cases occurred in children of school age and $10 \%$ of cases in adults. Chronic tonsillitis has the highest prevalence rate according to epidemiological data of ENT disease in seven provinces in Indonesia in 1994-1996. This stuudy aimed to obtain data about the health survey of throat among Tinoor Dua villagers. This study used a descriptive observational method and a cross sectional design. Overview of throat health status of each respondent was obtained by checking the size, surface, and color of tonsils and pharynx. The examination showed that most respondents had normal tonsil and pharynx. Conclusion: Most of the Tinoor Dua villagers had good throat health status.
\end{abstract}

Keywords: throat health status, examination of the throat

\begin{abstract}
Abstrak: Faringitis merupakan penyakit yang umum terjadi pada dewasa dan anak-anak. Kira-kira $15-30 \%$ kasus faringitis terjadi pada anak-anak usia sekolah dan 10\% kasus pada orang dewasa. Tonsilitis kronik memiliki angka prevalensi tertinggi menurut data epidemiologi penyakit THT pada tujuh provinsi di Indonesia pada tahun 1994-1996. Penelitian ini bertujuan untuk memperoleh data tentang survei kesehatan tenggorokan di Desa Tinoor Dua. Penelitian ini menggunakan metode deskriptif observasional dan desain potong lintang. Gambaran kesehatan tenggorokan setiap responden dilihat dengan memeriksa ukuran, permukaan, warna tonsil dan faring. Hasil pemeriksaan menunjukkan bahwa umumnya responden mempunyai tonsil dan farin normal. Simpulan: Umumnya warga Desa Tinoor Dua mempunyai gambaran kesehatan tenggorokan baik.
\end{abstract}

Kata kunci: kesehatan tenggorokan, pemeriksaan tenggorokan

Faring merupakan pipa berotot berbentuk seperti cerobong yang letaknya bermula dari bagian dasar tengkorak sampai persambungannya dengan esofagus pada ketinggian tulang rawan (kartilago) krikoid. ${ }^{1}$ Faring terbagi atas tiga bagian, yaitu nasofaring, orofaring dan laringofaring (hipofaring). Faring mempunyai unsur-unsur, yaitu mukosa, palut lendir (mukosa blanket) dan otot. ${ }^{2}$

Tonsil berbentuk oval dengan panjang dua sampai lima sentimeter, masing-masing tonsil mempunyai 10-30 kriptus yang meluas ke dalam jaringan tonsil. Fosa tonsilaris tidak diisi seluruhnya oleh tonsil, daerah kosong di atasnya dikenal sebagai fosa supratonsilaris. Bagian luar tonsil terikat longgar pada muskulus konstriktor faring superior, sehingga tertekan setiap kali makan. $^{3}$

Dalam keadaan normal tonsil berfungsi untuk membantu mencegah terjadinya infeksi. Tonsil bertindak seperti penyaring untuk memperangkap bakteri dan virus 
yang masuk ke tubuh melalui mulut dan sinus. Tonsil juga turut menstimulasi sistem imun untuk memproduksi antibodi untuk membantu melawan infeksi. Tonsil terletak di lokasi yang sangat memungkinkan terpapar benda asing dan patogen, selanjutnya membawanya ke sel limfoid. $^{3}$ Pembesaran tonsil menunjukkan adanya proses peradangan yang terjadi atau infeksi yang berlangsung kronis. ${ }^{4}$

Cincin Waldeyer merupakan jaringan limfoid yang membentuk lingkaran di faring yang terdiri dari tonsil palatina, tonsil faringeal (adenoid), tonsil lingual, dan tonsil tubal. ${ }^{2}$ Cincin Waldeyer berfungsi sebagai benteng bagi saluran makanan maupun saluran napas terhadap serangan kuman-kuman yang ikut masuk bersama makanan atau minuman dan udara saat pernapasan. Selain itu, anggotaanggota cincin Waldeyer dapat menghasilkan antibodi dan limfosit. ${ }^{5}$

Faringitis merupakan penyakit umum pada dewasa dan anak-anak. Faringitis merupakan peradangan dinding faring yang dapat disebabkan oleh virus (40-60\%), bakteri (lima sampai $40 \%$ ), alergi, trauma, toksin dan lain-lain. ${ }^{2}$ Anak-anak dengan usia lima sampai lima belas tahun tahun merupakan kelompok usia yang paling rentan untuk terinfeksi faringitis. ${ }^{6}$

Tonsilitis merupakan peradangan pada organ tonsil bersama pengumpulan leukosit, bakteri patogen, dan juga sel-sel epitel mati. Data epidemiologi penyakit THT pada tujuh provinsi di Indonesia pada tahun 1994-1996 menunjukkan bahwa prevalensi kejadian tonsilitis kronik ialah yang tertinggi setelah nasofaring akut (4,6\%) yaitu sebanyak 3,8\%. ${ }^{6}$

Masyarakat yang tinggal di daerah dataran tinggi umumnya banyak mengkonsumsi makanan pedas, meminum minuman panas atau hangat dan merokok. Semua ini dikarenakan suhu udara di daerah dataran tinggi yang dingin. Mengonsumsi makanan dan minuman dengan suhu ekstrim, merokok dan meminum alkohol merupakan faktor resiko yang dapat menyebabkan gangguan kesehatan tenggorokan. Penduduk yang tinggal di Sulawesi menyukai makanan dengan cita rasa pedas. ${ }^{7}$ Desa Tinoor Dua merupakan salah satu dataran tinggi di Sulawesi. Dikarenakan hal tersebut maka peneliti tertarik untuk melakukan penelitian tentang survei kesehatan tenggorokan di Desa Tinoor Dua.

\section{METODE PENELITIAN}

Metode penelitian yang digunakan adalah deskriptif dengan pendekatan potong lintang. Populasi penelitian ialah masyarakat yang tinggal di Desa Tinoor Dua. Sampel penelitian ialah warga Desa Tinoor Dua yang bersedia mengikuti penelitian.

Penelitian ini dilakukan dengan memeriksa tenggorokan responden secara langsung untuk mendapatkan status kesehatan tenggorokan. Variabel penelitian yaitu ukuran tonsil, permukaan tonsil, warna tonsil, warna faring, dan gambaran faring.

\section{HASIL PENELITIAN}

Total responden yang mengikuti penelitian berjumlah 42 orang. Data hasil pemeriksaan tenggorokan responden yang didapat disajikan dalam Tabel 1.

Tabel 1. Distribusi gambaran ukuran tonsil warga Desa Tinoor Dua

\begin{tabular}{cccc}
\hline \multicolumn{3}{c}{ Ukuran Tonsil } & Jumlah \\
\hline T1 & T2 & T3 & \\
30 & 9 & 3 & 42 \\
\hline
\end{tabular}

Tabel 2 . Distribusi gambaran permukaan tonsil warga Desa Tinoor Dua

\begin{tabular}{ccc}
\hline \multicolumn{3}{c}{ Permukaan Tonsil } \\
\hline Normal & Kripta Melebar & Jumlah \\
37 & 5 & 42 \\
\hline
\end{tabular}

Tabel 3. Distribusi gambaran warna tonsil warga Desa Tinoor Dua

\begin{tabular}{ccc}
\hline \multicolumn{3}{c}{ Warna Tonsil } \\
\hline Normal & Hiperemis & Jumlah \\
39 & 3 & 42 \\
\hline
\end{tabular}


Tabel 4. Distribusi gambaran warna faring warga Desa Tinoor Dua

\begin{tabular}{ccc}
\hline \multicolumn{3}{c}{ Warna Faring } \\
\hline Normal & Hiperemis & Jumlah \\
40 & 2 & 42 \\
\hline
\end{tabular}

Tabel 5. Distribusi gambaran gambaran faring warga Desa Tinoor Dua

\begin{tabular}{ccc}
\hline \multicolumn{3}{c}{ Gambaran Faring } \\
\hline Granula & Granula & Jumlah \\
Hipertrofi - & Hipertrofi + & \\
40 & 2 & 42 \\
\hline
\end{tabular}

\section{BAHASAN}

Berdasarkan penelitian yang telah dilakukan dapat dilihat bahwa hasil survei kesehatan tenggorokan di Desa Tinoor Dua menunjukkan umumnya warga memiliki kesehatan tenggorokan yang baik. Pada pemeriksaan tenggorokan yang dilakukan kebanyakan warga mendapatkan hasil pemeriksaan yang normal.

Penelitian ini mendukung penelitian sebelumnya mengenai gambaran kesehatan tenggorokan di daerah yang jauh dari perkotaan dan paparan faktor predisposisi. Seringnya mengonsumsi makanan pedas secara berkala dapat mengiritasi mukosa faring dan esofagus yang meningkatkan terjadinya inflamasi kronik. Meminum minuman panas juga berefek traumatik yang dapat merusak mukosa pada permukaan saluran cerna seperti faring dan esofagus. $^{8} \quad$ Penelitian ini mendukung mengenai kualitas udara di pedesaan yang lebih baik daripada di perkotaan jika dilihat dari hasil survei kesehatan yang telah dilakukan. ${ }^{9}$

\section{Limitasi penelitian}

Meskipun dalam penelitian ini didapatkan gambaran tentang kesehatan tenggorokan, namun peneliti menyadari bahwa hasil penelitian ini masih kurang akurat karena jumlah sampel dalam populasi yang masih kurang sehingga masih belum dapat dijadikan tolak ukur untuk gambaran kesehatan tenggorokan secara umum. Masalah gangguan kesehatan tenggorokan tidak hanya ditinjau dari faktor makanan dan udara yang dingin, faktor yang lain juga dapat menyebabkan gangguan seperti tingkat paparan polusi, tingkat kebersihan makanan serta pengetahuan setiap orang tentang kesehatan yang kurang.

\section{SIMPULAN}

Survei kesehatan tenggorok yang dilakukan pada masyarakat yang tinggal di Desa Tinoor Dua meliputi pemeriksaan ukuran tonsil, permukaan tonsil, warna tonsil, warna faring, dan gambaran tonsil. Umumnya warga Desa Tinoor Dua yang telah diperiksa pada survei kesehatan tenggorokan memiliki gambaran kesehatan yang baik.

\section{SARAN}

Disarankan untuk penelitian lebih lanjut mengenai survei kesehatan tenggorokan di daerah dataran tinggi. Sampel dengan jumlah yang lebih banyak diperlukan untuk mendapatkan hasil penelitian yang lebih akurat.

\section{DAFTAR PUSTAKA}

1. Pearce EC. Anatomi dan fisiologi untuk paramedis. Jakarta: PT Gramedia Pustaka Utama, 2009; p. 218.

2. Soepardi EA, Iskandar N, Bashiruddin J, Restuti RD. Buku ajar penyakit THT UI (Edisi ke-6). Jakarta: Balai Penerbit FKUI, 2007; p. 217-21.

3. Amalia N. Karakteristik penderita tonsilitis kronis di RSUP H. Adam Malik Medan tahun 2009. [cited 2014 September 23]. Available from: http://repository.usu.ac.id/bitstream/1234567 89/27640/4/Chapter\%20II.pdf.

4. Wibowo DS. Anatomi tubuh manusia. Jakarta: Grasindo, 2008; p. 79-80.

5. Herawati S, Rukmini S. Ilmu penyakit telinga hidung tenggorokan. Jakarta: EGC, 2003; p.15-47.

6. Agustia D, Rini N, Rasmaya N, Suherman F, Putu TI. Penentuan Streptococcus group A penyebab faringitis pada anak menggunakan mcisaac score dan rapid antigen detection test (RADT) dalam upaya penggunaan antibiotik secara bijak. Biologi. 2013;16:7.

7. Redaksi Agromedia. Petunjuk praktik 
Wiyanto, Pelealu, Tumbel: Survei kesehatan tenggorokan ...

bertanam cabai. Jakarta: PT Agromedia Pustaka, 2011; p. 6-7.

8. Anggraini SM. Hubungan faringitis kronik dengan riwayat konsumsi makanan minuman ekstrem secara suhu dan rasa. 2011 [cited 2014 Desember 23]. Available from: http://eprints.undip.ac.id/37318/

9. Lantemona R. Survei kesehatan tenggorok pada siswa Sekolah Menengah Kejuruan 2 Kota Manado dan siswa Sekolah Menengah Kejuruan 1 Desa Tumpaan. [Skripsi]. Manado: Universitas Sam Ratulangi, 2013. 